\title{
Genetic transformation: a short review of methods and their applications, results and perspectives for forest trees
}

\author{
L Jouanin 1, ACM Brasileiro 1, ${ }^{*}$, JC Leplé 2, G Pilate 2, D Cornu 2
}

1 INRA, laboratoire de biologie cellulaire, route de Saint-Cyr, 78026 Versailles Cedex;

2 INRA, station d'amélioration des arbres forestiers, Ardon, 45160 Olivet, France

(Received 10 September 1992; accepted 11 February 1993)

\begin{abstract}
Summary - This report reviews the state-of-the-art in plant genetic engineering, covering both direct and indirect gene transfer methods. The application of these techniques to forest trees has been discussed and a summary of the published results given. An overview of the possibilities of introducing genes of agronomic interest to improve some characteristics such as resistance to pests and modifications of phenotypic traits has been examined.
\end{abstract}

\section{Agrobacterium / biotechnology / forest tree / genetic transformation}

Résumé - La transformation génétique : résultats et perspectives pour les arbres forestiers. Cet article fait le point sur les techniques directes et indirectes de transformation génétique des plantes. Leur application pour la transformation des arbres forestiers est discutée et une liste des résultats déjà publiés est établie. Les différents gènes d'intérêt agronomique qui peuvent être introduits afin d'améliorer des caractères comme la résistance aux pathogènes et des modifications du phénotype sont détaillés.

\section{Agrobacterium / arbres forestiers / biotechnologie / transformation génétique}

\section{INTRODUCTION}

Biotechnology includes tissue culture, molecular biology and genetic transformation. This field of research can accelerate tree improvement programs in a number of ways. Tissue culture not only offers the potential to multiply selected genotypes efficiently and rapidly, but is also essential for the multiplication of transformed genotypes. Molecular biology and genetics provide insight into the nature, organization, and control of genetic variation (Cheliak and Rogers, 1990).

* Present address: Embrapa/Cenargen, Sain Parque Rural 70770, Brazilia-DF, Brazil. 
Transgenic plant recovery is a relatively new domain and was first attained with model plants such as tobacco. The introduction and expression of foreign DNA in a plant genome requires several steps: introduction of DNA into a cell, selection and growth of this cell, and regeneration of an entire plant. Continuing progress is made in obtaining transgenic plants from annual crops. However, it has been slower in tree species which can be transformed but are more difficult to regenerate, in part due to inefficiencies of in vitro culture systems. Thus, many public and private laboratories are working on improving tree culture systems. In this paper, we provide some insight into the main transformation procedures developed for crop plants and review the results obtained with forest trees.

\section{GENETIC TRANSFORMATION METHODS}

Different systems can be used to introduce foreign DNA into a plant genome. These methods include biological systems based on the pathogenic bacteria Agrobacterium tumefaciens and $A$ rhizogenes, or physical and chemical systems such as microinjection, electroporation, chemical poration and microprojectile bombardment. Many other ways of introducing DNA into the plant cell have been tested, and have been recently reviewed by Potrykus (1991).

\section{Agrobacterium-mediated transformation}

A tumefaciens and $A$ rhizogenes are considered as natural genetic engineers due to their ability to transfer and integrate DNA into plant genomes through a unique intergeneric gene transfer mechanism.
Both are phytopathogenic bacteria of the Rhizobiaceae family. A tumefaciens is the causative agent of crown gall disease and A rhizogenes is responsible for hairy root disease. These bacteria are pathogenic in a wide range of dicotyledons and in some gymnosperms (De Cleen and De Ley, $1976,1981)$. In particular, they have been the cause of problems in vineyards and fruit orchards in Eastern Europe. Monocotyledons are naturally resistant to Agrobacterium infection (De Cleene, 1985).

These diseases are caused by the transfer and integration into the plant genome of a portion of large plasmids (150$200 \mathrm{~kb}$ ) called pTi (tumor-inducing plasmids) from $A$ tumefaciens and $p R i$ (rootinducing plasmids) from $A$ rhizogenes (reviewed by Charest and Michel, 1991 ; Hooykaas and Schilperoort, 1992 ; Winans, 1992 ; Zambryski, 1992). The genes located in the transferred region, called $T$ DNA (transferred DNA) are integrated into the plant genome and expressed in the plant cells. Some of these genes (oncogenes) promote hormone synthesis or modifications in hormone content that alter the growth regulator balance of the plant tissue, thus changing their growth characteristics. The tumors obtained after $A$ tumefaciens inoculation result from the expression of the auxin and cytokinin synthesis genes present on pTi T-DNA. In the case of $A$ rhizogenes, expression of several genes called rolA, B and $C$ (rootincluding loci) induces root formation at the inoculation point. Up to now this root induction mechanism has not been completely elucidated.

The T-DNA genes are not involved in TDNA transfer mechanism and can be replaced by other genes without affecting transfer efficiency. Two direct repeats of $24 \mathrm{bp}$ at the borders of all T-DNA are needed for their efficient transfer. Another sequence named overdrive near the right border enhances the transfer. The other 
essential part of pTi and pRi is the virulence region (vir). The vir genes are responsible for the processing of the T-DNA and its transfer to the plant cell. Figure 1 presents a schematic map of the Ti plasmid showing the most important regions, the vir-region as already mentioned, the Tregion (called T-DNA when transferred in transformed plant cells) and the regions implicated in the replication of the plasmid in the bacteria and in the conjugative transfer between bacteria.

For plant genetic engineering the oncogenes need to be deleted from $\mathrm{pTi}$ as they are not compatible with regeneration. Entire plants containing $p R i$ T-DNA can be regenerated from transformed roots. However, the plants expressing $\mathrm{pRi}$ oncogenes present a specific phenotype (wrinkled leaves, root plagiotropism and reduction of apical dominance ; Tepfer, 1984) which is often incompatible with their use in plant breeding programs.

Two different strategies can be used for gene integration with the Agrobacterium system. In a cointegrate vector (fig $2 \mathrm{~A}$; Zambryski et al, 1983), pTi T-DNA oncogenes are replaced via homologous recom-

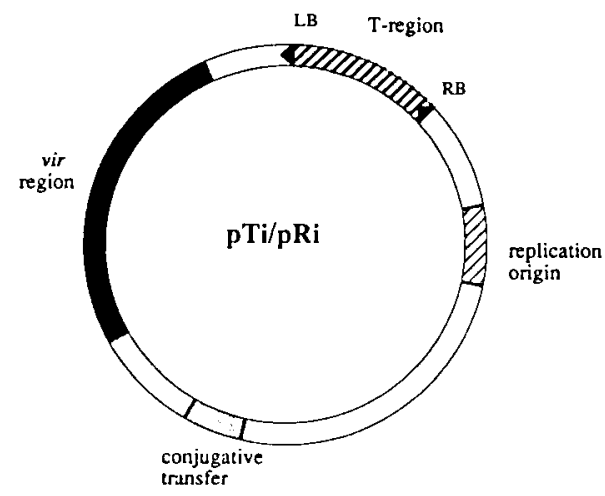

Fig 1. Schematic map of a Ri or Ti plasmid. The main regions are indicated: $v i r$ region $=$ virulence region, T-region limited by the right and left border sequences (RB and LB), replication origin and conjugative transfer. bination by a DNA fragment containing the gene(s) of interest and if necessary a marker gene flanked with vector sequences. This strategy can also be used with $\mathrm{pRi}$ without removing the oncogenes which allow the root formation. However, the strategy used in most cases involves a binary system (fig 2B; Hoekema et al, 1983). In this case, the agrobacteria used for transformation contain $\mathrm{Ti}$ or Ri plasmids with intact virulence regions but with deletion of their entire T-region (including the border sequences). These are termed disarmed strains. The gene of interest and if necessary a selectable marker gene are cloned between the border sequences into a second small plasmid. For plant transformation, the binary plasmid is introduced into a disarmed Agrobacterium. The most currently used technique to obtain transgenic plants is the cocultivation of plant explants, eg leaf, stem, or root fragments, embryos with the Agrobacterium containing the gene of interest in its T-region. During this cocultivation step, the wounded plant cells are in contact with the Agrobacterium and the transfer of T-DNA occurs. Then the agrobacteria are eliminated and the plant explants are transferred onto a regeneration medium. In complement to the elements needed for regeneration of shoots, the medium contains 2 kinds of antibiotics, one to kill the residual agrobacteria (decontamination) and the other to select the transformed plant cells. Figure 3 summarizes the different steps in the procedure developed for poplar stem fragment cocultivation according to Leplé et al (1991).

\section{Direct gene transformation}

Direct transformation techniques overcome Agrobacterium host range limitations. These methods are generally based on the use of protoplasts or tissues from which efficient regeneration can be 
A)

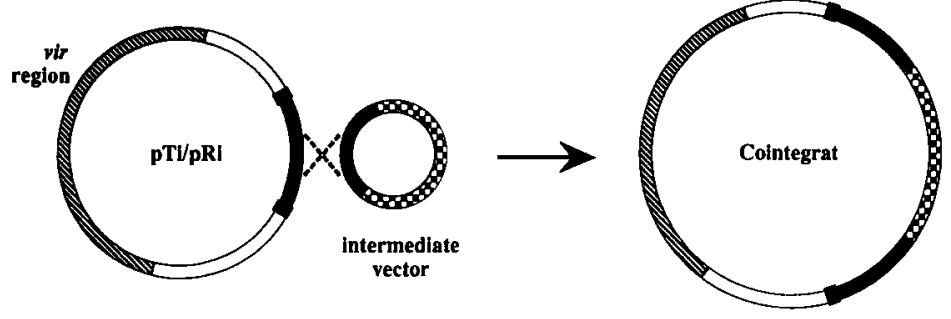

B)

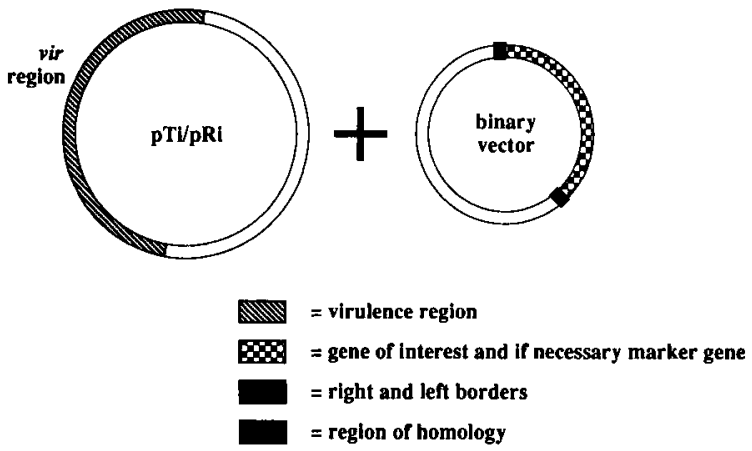

Fig 2. Strategies for use of Ri or Ti plasmids in gene transfer. A: Intermediate vector strategy. The gene of interest cloned in a vector (pBR322) only able to replicate in $E$ coli is integrated via recombination into the T-region of a pTi. In this T-region, still possessing border sequences, the oncogenes were replaced by pBR322 sequences allowing homologous recombination. B: Binary strategy. The gene of interest and if necessary a marker gene are introduced between the border sequences in a small plasmid able to replicate in Agrobacterium. The Agrobacterium strain generally contains a disarmed pTi or pRi possessing an intact region of virulence but deleted of its entire T-region.

achieved. With these methods, transient expression (expression of the introduced gene without integration in the plant genome) of the transferred gene is often observed. However, stable transformation after integration in the plant genome can also be achieved.

Different means can be used to render permeable the plant protoplast membrane to allow uptake of naked DNA. Some authors have used polyethylene glycol (PEG) or polyvinyl alcohol (PVA), but the transformation frequency has sometimes been low (Kruger-Lebus and Potrykus, 1987). Another method which can increase the transformation rate is electroporation. In this method, after or without pretreatment with PEG or PVA, the protoplasts are submitted to a high-voltage electric pulse which enhances DNA penetration into the plant cell (Crossway et al, 1986 ; Fromm et al, 1986).

Microjection permits direct and precise delivery of DNA into the plant protoplasts using a microsyringe containing the DNA in solution. However, this technique is extremely delicate and requires the use of expensive equipment (Reich et al, 1986).

Microprojectile bombardment is a novel technique in which small tungsten or gold 


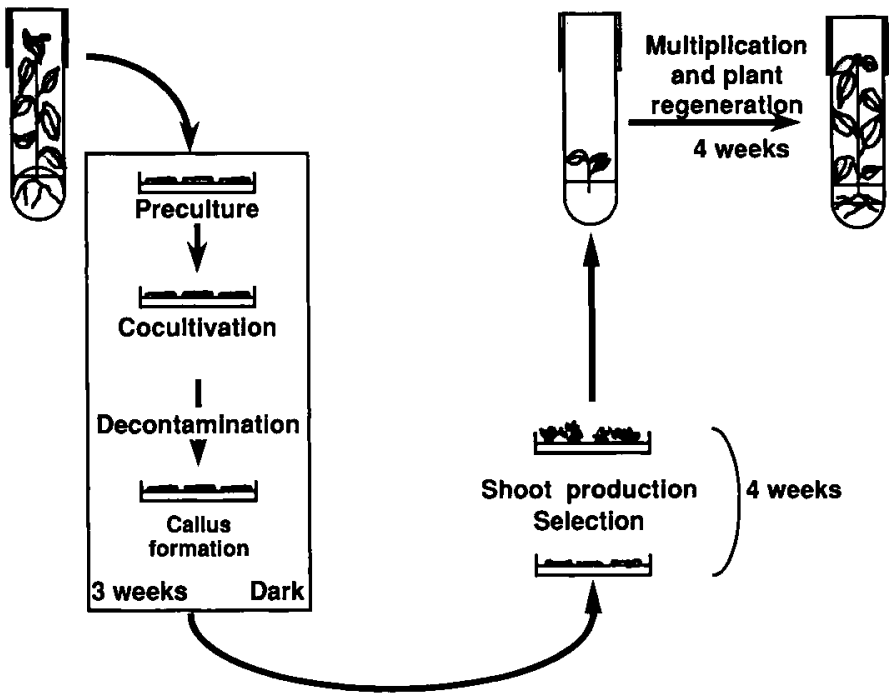

Fig 3. Principle of the cocultivation transformation procedure for a hybrid poplar according to Leple et al (1992). The different steps of the experiment and their duration are given.

particles coated with DNA are accelerated with a gun to velocities that permit penetration of intact cells (Klein et al, 1987 ; Christou et al, 1988 ; Sautter et al, 1991). The use of intact cells or tissues is a major advantage because it bypasses the need for regeneration procedures from protoplasts. Moreover, this technique allows the study of gene expression in organized tissues without the need to regenerate entire transformed plants.

Many other techniques have also been tested with the aim of introducing DNA into plant cells (laser microbeam, pollen tubemediated delivery, ultrasonication, etc) but, in most of them, only transient expression or non-reproducible results have been observed (Potrykus, 1991). All of these techniques have their limitations. The transformation method selected will depend on the species and characteristics of the plant to be transformed.

\section{MARKER GENES}

Two strategies can be used to recover transgenic plants after transformation: screening of all regenerated plants for expression of a reporter gene, and/or selection of transformed plants for resistance to a selectable agent. The marker genes are chimeric constructions containing plant expression signals fused to the coding sequence of a gene of bacterial or other origin. These regulatory sequences (promoter and polyadenylation signal), allowing expression in plant cells, are generally derived from genes of the pTi T-DNA (nopaline synthase, octopine synthase, mannopine synthase, etc) or from the 195 and $35 \mathrm{~S}$ transcripts of the cauliflower mosaic virus. Among the more frequently used reporter genes, the B-glucuronidase (GUS) gene is very useful since its enzyme activity can be easily visualized by formation of 
a blue precipitate in the presence of XGluc (5-bromo-4-chloro-3-indolyl glucuronide) in histochemical assays or measured by fluorimetry in the presence of MUG (4-methyl umbelliferyl glucuronide) as substrate (Jefferson et al, 1987). The introduction of a plant intron into the coding sequence of the GUS gene prevents its expression in Agrobacterium. This characteristic permits the first steps of the transformation to be followed, since it allows easy visualization of the transformed plant cells without the problems caused by the presence of agrobacteria at the inoculation point (Vancanneyt et al, 1990).

Among the selectable markers used to select transformed cells on the culture media, the neomycin phosphotransferase (NPTII) gene (Fraley et al, 1983 ; HerrellaEstrella et al, 1983) is widely used. The expression of this gene confers resistance to different antibiotics (kanamycin, neomycin, paronomycin, geneticin). The activity of this selectable gene product is easily detectable. Hygromycin phosphotransferase (HPT, Waldron et al, 1985) is also very efficient but less frequently used and can constitute an alternative when 2 markers are necessary or when the selection with kanamycin does not work well.

Genes conferring herbicide resistance can also be used for selection of transformed cells. In this case, the selective agent confers a new agronomically important trait to the transgenic plants. Herbicides that have been used for selection of transformed woody cells are phosphinotricin (De Block, 1990) and chlorsulfuron (Miranda Brasileiro et al, 1992). The resistance to the former herbicide is conferred by the expression of the detoxification gene bar for Streptomyces hygroscopinus which encodes a phosphinotricin acetyltransferase enzyme (PAT) preventing the action of the herbicide (Thompson et al, 1987). The resistance to the latter herbicide is conferred by a gene isolated from a mutant Arabidopsis thaliana line encoding a chlorsulfuron-resistant acetolactate synthase (Haughn et al, 1988).

\section{PRELIMINARY RESULTS WITH FOREST TREES}

After excision from the plant, tumors or roots obtained following wild-type Agrobacterium inoculation are generally able to grow on a hormone-free medium. Such results have been reported for many forest trees including conifers (reviewed in Charest and Michel, 1991) and have not been reviewed in this publication. These experiments show the ability of Agrobacterium to transform forest tree cells. Similarly, most of the results obtained by direct transformation procedures concern the transient expression of genes $\approx 24 \mathrm{~h}$ after DNA introduction (reviewed in Charest and Michel, 1991). These results demonstrate that DNA has been introduced into the plant cell but probably without stable integration in the plant genome. Moreover, there is a distinct difference between the observation of tumor formation after inoculation, transient expression after electroporation or microprojection, and the regeneration of an entire transformed plant.

Indeed, all of the regeneration procedures so far described involve a tissue culture regeneration system. This regeneration can be based on organogenesis from an explant (leaf, root, stem) or from an embryogenic culture (directly or through protoplast isolation).

The most rapid advances in genetic engineering to data have been obtained with woody angiosperms such as poplars. $\mathrm{Hy}$ brid poplars are good models for forest tree transformation since they are easily micropropagated in vitro, are generally very sensitive to Agrobacterium, and able to regenerate entire plants from different explants. Several publications report the 
obtention of transgenic hybrid poplars mainly using Agrobacterium (Fillatti et al, 1987 ; De Block, 1990 ; Klopfenstein et al, 1991 ; Miranda Brasiliero et al, 1991, 1992 ; Devillard, 1992 ; Leplé et al, 1992 ; Nilsson, 1992). Transgenic trees have also been reported for walnut via Agrobacterium transformation of somatic embryos (McGranahan et al, 1988, 1990 ; JayAllemand et al, 1991). Recently microprojection has been used with poplar leaves (McCown et al, 1991) or embryogenic cells of yellow poplar (Liriodendron tulipifera ; Wilde et al, 1992) followed by the production of transgenic trees. Table I summarizes the published results for different forest trees and the characteristics of the transgenic plants.
Regarding the recovery of transgenic conifers, up to now only transgenic larches (Larix decidua ; Huang et al, 1991) via $A$ rhizogenes transformation and transgenic embryos and plants of white spruce (Picea glauca) via microprojection (Ellis et al, 1993) have been reported. In conifer species, many publications report tumor formation after Agrobacterium inoculation, and transient expression via protoplast electroporation or via microprojection of embryogenic tissues (reviewed in Charest and Michel, 1991). Recently, Robertson et al (1992) have reported the obtention of stable transformed calli of Norway spruce (Picea abies) by microprojectile bombardment of somatic embryo explants. Conifer transformation and regeneration is a rela-

Table I. Genetic transformation of tree species.

\begin{tabular}{|c|c|c|c|}
\hline Species & Method & Transferred genes & Ref \\
\hline $\begin{array}{l}\text { Allocasuarina verticillata } \\
\text { Azadirachta indica } \\
\text { Juglans regia } \\
\text { Juglans regia } \\
\text { Juglans nigra } \times J \text { regia } \\
\text { Liriodendron tulipifera } \\
\text { Populus alba } P \text { grandidentata } \\
\text { Populus alba } P \text { tremula } \\
\text { Populus tricocarpa } P \text { deltoides } \\
\text { Populus tremula } P \text { alba } \\
\text { Populus alba } \times \text { grandidentata } \\
\text { Populus nigra } \times P \text { trichocarpa } \\
\text { Populus alba } P \text { grandidentata } \\
\text { Populus tremula } \times P \text { alba } \\
\text { Populus tremula } \times P \text { tremuloides } \\
\text { Populus tremula } \times \text { tremuloides } \\
\text { Populus tremula } \times P \text { alba } \\
\text { Populus tremula } \times \text { alba }\end{array}$ & $\begin{array}{l}\text { A rhizogenes } \\
\text { A tumefaciens } \\
\text { A tumefaciens } \\
\text { A tumefaciens } \\
\text { A tumefaciens } \\
\text { Microprojection } \\
\text { A tumefaciens } \\
\text { A tumefaciens } \\
\text { A tumefaciens } \\
\text { A tumefaciens } \\
\text { Microprojection } \\
\text { Microprojection } \\
\text { A tumefaciens } \\
\text { A tumefaciens } \\
\text { A tumefaciens } \\
\text { A tumefaciens } \\
\text { A tumefaciens } \\
\text { A rhizogenes }\end{array}$ & 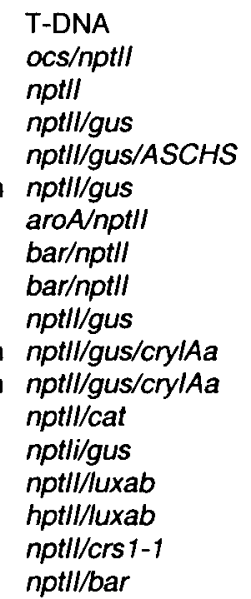 & $\begin{array}{l}\text { Phelep et al, } 1992 \\
\text { Naina et al, } 1989 \\
\text { McGranahan et al, } 1988 \\
\text { McGranahan et al, } 1990 \\
\text { Jay-Allemand et al, } 1991 \\
\text { Wilde et al, } 1991 \\
\text { Fillatti et al, } 1987 \\
\text { De Block, } 1990 \\
\text { De Block, } 1990 \\
\text { Miranda Brasileiro et al, } 1991 \\
\text { McCrown et al, 1991 } \\
\text { McCown et al, } 1991 \\
\text { Klopfenstein et al, } 1991 \\
\text { Leplé et al, } 1992 \\
\text { Nilsson et al, } 1992 \\
\text { Nilsson et al, } 1992 \\
\text { Miranda Brasileiro et al, } 1992 \\
\text { Devillard, } 1992\end{array}$ \\
\hline
\end{tabular}

Abbreviations: T-DNA: wild type pRi T-DNA; ocs. octopine synthase; nptll: neomycin phosphotransferase II; gus: $\beta$ glucuronidase; ASCHS: chalcone synthase antisense; aroA: mutated 5 enolpyruvilshikimate-3-phosphate synthase; bar. phosphinotricin acetyltransferase; crylAa. Bacillus thuringiensis $\delta$-endotoxin; cat. chloramphenicol acetyltransferase; hptll: hygromycin phosphotransferase; crsl-1: mutated acetolactate synthase; $/ u \times A B$ : bacterial luciferase. 
tively new field and different approaches are being tested.

\section{POTENTIAL TRAITS TO INTRODUCE}

An important question is that of which genes to transfer in woody species. Fundamentally, introducing genes into a forest tree genome would help in elucidating aspects of gene control or expression and metabolism. For angiosperms, gene regulation is probably similar for woody and non-woody plants. However, very little information is available on gymnosperms (conifers). The ability to introduce a gene or its regulatory sequences into conifers will advance our understanding of the role of genes, promoters or control regions. Up to now, there has been a lack of understanding of the structure and function of conifer genes, since only few of them have been characterized. Some of these questions could be solved by using transient expression assays via protoplast electroporation or by microprojection of organized tissues.

Practically speaking, transgenic trees could constitute part of tree improvement programs. Many potential applications of new traits conferred by a single gene could be envisaged such as resistance to herbicides and to diseases, as well as modifications in phenotypic characters such as sterility or wood quality. Different genes able to confer new properties already used in annual plants could be introduced into forest trees.

Herbicide-resistant trees could be bred by different strategies: introduction of a mutant gene coding for a modified enzyme (resistance to glyphosate and chlorsulfuron), overproduction of the target enzyme (glyphosate) or detoxification of the herbicide (phosphinotricin, bromoxynil). As weed problems are mostly found in tree nurseries, this application should provide a route for more efficient establishment of young trees in nurseries, and an improvement in nursery management techniques.

Two strategies for obtaining insectresistant trees could be tested: expression of $\delta$-endotoxin genes of Bacillus thuringiensis $(\mathrm{Bt})$ or of proteinase inhibitor $(\mathrm{PI})$ genes interfering with insect digestion. Bt genes with activity against lepidopteran, coleopteran and dipteran insect species (Höfte and Whiteley, 1989) have been isolated. Up to now some bio-insecticides containing Bt preparations have been used against forest phytophage insects. Expression of the corresponding gene in a transgenic tree could enhance its resistance against this pest. Genes coding for different types of protease inhibitions are available and the effect of their expression on insect pests could be tested. Moreover, they could be tested in combination with Bt genes (Brunke and Mensen, 1991).

Several strategies tested in annual plants, such as the expression of the viral coat protein, antisense RNA and interference with subviral RNA molecules (reviewed by Gadani et al, 1990 ; Szybalski, 1991) have been shown to be efficient in the control of virus diseases. Such strategies could be tested for virus protection in trees.

In poplar, enzymes encoded by woundresponsive genes that could be involved in pathogen resistance (chitinases and trypsin inhibitors) have been isolated and characterized (Bradshaw et al, 1989 ; Davis et al, 1991). Since introduction of a chitinase gene in tobacco and rapeseed was found to enhance resistance to a fungal pathogen (Broglie et al, 1991), this strategy could be tested in trees. Likewise, different strategies could be tested to obtain trees resistant to bacterial diseases (Lamb et al, 1992).

Another possibility is to modify phenotypic characteristics. One approach is to in- 
terfere with the physiology of the plant by reducing the expression of a gene via antisense RNA strategy (Van der Krol et al, 1990). This strategy could help to modify expression of a gene, thus changing the phenotype. However, the prerequisite for such an approach is the identification and isolation of genes that affect the character in question. Up to now, very few forest tree genes have been isolated and characterized. Several research projects are underway to obtain this information. In particular, poplar genes involved in the lignin biosynthesis pathway are available, such as those encoding O-methyltransferase (OMT ; Bugos et al, 1991 ; Dumas et al, 1992) and cinnamyl alcohol deshydrogenase (CAD ; van Doorsselaere et al, unpublished results). Reduction of the activity of OMT and CAD enzymes could be studied using the antisense strategy and lead to modifications in the lignin content or in its composition. As part of the same approach, another project is to express an antisense chalcone synthase gene (CHS) in walnut in order to modify its content in phenolic compounds and thus indirectly modify rhizogenesis (Jay-Allemand et al, 1991). Moreover, since most of these enzymes are implicated in pathogen interaction, the effect of their over expression could provide information on their possible role in plant defense against pathogens.

Several publications report on the production of transgenic poplars expressing genes of interest. Most of them refer to plants which express genes conferring resistance to herbicides: glyphosate (Fillatti et al, 1987), phosphinotricine (De Block, 1990 ; Devillard, 1992) or chlorsulfuron (Miranda Brasileiro et al, 1992). However, insect-resistant poplars expressing a Bacillus thuringiensis toxin gene have also been obtained (McCown et al, 1991).

The potential impact of the release of transgenic trees in the fields is different from that associated with annual crop plants, due to the long life cycle of tree species. In particular, we may question the most appropriate way of propagating the newly introduced trait. Problems will vary depending on the species. In the case of clonal or multiclonal strategy for production, forest trees such as hybrid poplars, which are mostly propagated by cutting, are easily multiplied to obtain stable transgenic clonal propagations. The problem is not so easy to solve for forest species which are propagated by seed. Indeed, how will it be possible to stably incorporate the trait? At present, not all the elements to answer this question have been obtained.

Perhaps most importantly, if genetically engineered trees that can reproduce sexually are used in reforestation programs, should one be concerned about the transmission of foreign DNA into the wild population (Cheliak and Rogers, 1990)? For example, it is conceivable that the introduction of a herbicide-resistant gene could be transferred by sexual reproduction to wild trees (Keeler, 1989). To avoid this spread, technology to obtain sterile transgenic trees may be envisaged using, for example, destruction of pollen by expression of a gene coding for an RNAase in tapetal cells, as already attained in tobacco and rapeseed (Mariani et al, 1990).

Finally, the introduction of pest resistance in trees could involve the development of tolerance by the attacking organism. This is critical for long-life forest trees which have to maintain defensive capacity against pathogens, despite enormous differences in generation times (Raffa, 1989). The problem is to determine at what point the attacking pest will develop tolerance (Bishop and Cook, 1981).

Moreover, at the present time it is difficult to determine which government regulations will be put in place regarding the release of transgenic trees in the field. Despite the potential power that transforma- 
tion technology can provide, many aspects still need to be considered. However, it is clear that transformation technology will participate in the advancement of tree improvement programs in the future.

\section{REFERENCES}

Bishop JA, Cook LM (1981) Genetic Consequences of Man-Made Change. Academic Press, London

Brashaw HD, Hollick JB, Parsons TJ, Clarke HRG, Gordon M (1989) Systematically wound-responsive genes in poplar trees encode proteins similar to sweet potato sporamins and legume Kunitz trypsin inhibitors. Plant Mol Biol 14, 51-59

Broglie K, Chet I, Holliday M, Cressman R, Biddle $P$, Knowlton S, Mauvais J, Broglie R (1991) Transgenic plants with enhanced resistance to the fungal pathogen Rhizoctonia solani. Science $254,1194-1197$

Brunke KJ, Meeusen RL (1991) Insect control with genetically engineered crops. Trends Biotechnol 9, 197-200

Bugos RC, Chiang VLC, Campbell WH (1991) cDNA cloning, sequence analysis and seasonal expression of lignin-bispecific caffeic/ 5-hydroxyferulic acid O-methyltransferase of aspen. Plant Mol Biol 17, 1203-1215

Charest PJ, Michel MF (1991) Basics of Plant Genetics Engineering and Its Potential Application to Tree Species. Inf Rep PI-X-104, Petawawa Nat For Inst, Canada

Cheliak WM, Rogers DL (1990) Integrating biotechnology into tree improvement programs. Can J For Res 20, 452-463

Christou P, McCabe DE, Swain WF (1988) Stable transformation of soybean callus by DNA-coated gold particles. Plant Physiol 87 , 671-674

Crossway A, Oakes JV, Invine JM, Ward B, Knauf VC, Shewmaker CK (1986) Integration of foreign DNA following microinjection of tobacco mesophyll protoplasts. Mol Gen Genet 202, 179-185

Davis JM, Clarke HRG, Bradshaw HD, Gordon MP (1991) Populus chitinase genes: structure, organization, and similarity of translated sequences to herbaceous plant chitinases. Plant Mol Biol 17, 631-639

De Block M (1990) Factors influencing the tissue culture and the Agrobacterium tumefaciensmediated transformation of hybrid aspen and poplar clones. Plant Physiol 93, 1110-1116

De Cleene M (1985) The susceptibility of monocotyledons to Agrobacterium tumefaciens. Phytopathol Z 113, 81-89

De Cleene M, De Ley J (1976) The host range of crown gall. Bot Rev $42,389-466$

De Cleene M, De Ley J (1981) The host range of infectious hairy-root. Bot Rev 47, 147-194

Devillard C (1992) Transformation in vitro du tremble (Populus tremula $\times$ Populus alba) par Agrobacterium rhizogenes et régénération de plantes tolérantes au Basta. CR Acad Sci Ser 3: Sci Vie 314, 291-298

Dumas B, Van Doorsselaere J, Gielen J, Legrand $M$, Fritig $B$, Van montagu $M$, Inzé $D$ (1992) Nucleotide sequence of a complementary DNA encoding $O$-methyltransferase from poplar. Plant Physio/ 98, 796-797

Ellis DD, McCabe DE, Mclnnis S, Ramachandran $R$, Russell DR, Wallace KM, Martinell BJ, Roberts DR, Raffa KF, McCown BH (1993) Stable Tranformation of Picea Glauca by Particle Acceleration. Biotechnol 11, 84

Fillatti JJ, Sellmer J, McCown B, Haissig B, Comai L (1987) Agrobacterium-mediated transformation and regeneration of Populus. $\mathrm{Mol}$ Gen Genet 206, 192-199

Fraley RT, Rogers SG, Horsch RB, Sanders PR, Flick JS, Adals SP, Bittner ML, Brand LA, Fink CL, Fry JS, Galluppi GR, Goldberg SB, Hoffman NL, Woo SC (1983) Expression of bacterial gene in plants cells. Proc Natl Acad Sci USA 80, 4803-4807

Fromm ME, Taylor LP, Walbot V (1986) Stable transformation of maize after gene transfer by electroporation. Nature (Lond) 319, 791793

Gadani F, Mansky LM, Medici R, Miller WA, Hill $\mathrm{JH}$ (1990) Engineering of plant for virus resistance. Arch Virol 115, 1-21

Haughn GW, Smith J, Mazur B, Somenville C (1988) Transformation with a mutant Arabidopsis acetolactate synthase gene renders tobacco resistant to sulfonylurea herbicides. Mol Gen Genet 211, 266-271 
Herrella-Estrella L, De Block M, Messens E, Hernalsteens JP, Van Montagu M, Schell J (1983) Chimeric genes as dominant selectable markers in plant cells. EMBO J 2, 987-995

Höfte H, Whiteley HR (1989) Insecticidal crystal proteins of Bacillus thuringiensis. Microbiol Rev 5, 242-255

Hoekema A, Hirsch PR, Hooykaas PJJ, Schilperoort RA (1983) A binary plant vector strategy based on separation of vir and T-regions of the Agrobacterium tumefaciens Ti-plasmid. Nature (Lond) 303, 179-180

Hooykaas PJJ, Schilperoort RA (1992) Agrobacterium and plant engineering. Plant Mol Biol $19,15-38$

Huang Y, Diner AM, Karnosky DF (1991) Agrobacterium rhizogenes-mediated genetic transformation and regeneration of a conifer: Larix decidua. In Vitro Cell Dev Biol 27, 201-207

Jay-Allemand $C$, Jouanin L, Deng MD, Claudot AC, Drouet A, Cornu D (1991) Transfer of chalcone synthase antisense gene: new strategy for studying polyphenols involved in walnut rhizogenesis. In: Plant Science Today (De Kouchkovsky, ed) Les Colloques INRA, $305 \mathrm{p}$

Jefferson RA, Kavanagh TA, Bevan MW (1987) Gus fusions: $\beta$-glucoronidase as a sensitive and versatile gene marker in higher plants. EMBO J 6, 3901-3907

Keeler KH (1989) Can genetically engineered crops become weeds? Bio/Technology 7 , 1134-1139

Klein TM, Wolf ED, Wu R, Sanford JC (1987) High velocity microprojectiles for delivering nucleic acids into living cells. Nature (Lond) 327, 70-73

Klopfenstein NB, Shi NQ, Kernan A, McNabb HS, Hall RB, Hart ER, Thornburg RW (1991) Transgenic Populus hybrid express of wound inducible potato proteinase inhibitor-CAT gene fusion. Can J For Res 21, 1321-1328

Kruger-Lebus S, Potrykus I (1987) A simple and efficient method for direct gene transfer to Petunia hybrida without electroporation. Plant Mol Biol Rep 5, 289-294

Lamb CJ, Ryals JA, Ward ER, Dixon RA (1992) Emerging strategies for enhancing crop resistance to microbial pathogens. Bio/ Technology 10, 1436-1445
Leplé JC, Brasileiro ACM, Michel MF, Delmotte $F$, Jouanin L (1992) Transgenic poplars: expression of chimeric genes using four different constructs. Plant Cell Rep 11, 137-141

Mariani C, De Beuckeleer M, Truettner J, Leemans J, Goldberg RB (1990) Induction of male sterility in plants by a chimaeric ribonuclease gene. Nature (Lond) 347, 737-741

McCown BH, McCabe DE, Russell DR, Robison DJ, Barton KA, Raffa KF (1991) Stable transformation of Populus and incorporation of pest resistance by electric discharge particle acceleration. Plant Cell Rep 9, 590-594

McGranahan GH, Leslie CA, Uratsu SL, Martin LA, Dandekar AM (1988) Agrobacterium mediated transformation of walnut somatic embryos and regeneration of transgenic plants. Bio/Technology 6, 800-804

McGranahan GH, Leslie CA, Uratsu SL, Dandekar AM (1990) Improved efficiency of the walnut somatic embryo gene transfer system. Plant Cell Rep 8, 512-516

Miranda Brasileiro AC, Leplé JC, Muzzin J, Ounnoughi D, Michel MF, Jouanin L (1991) An alternative approach for gene transfer in trees using wild-type Agrobacterium strains. Plant Mol Biol 17, 441-452

Miranda Brasileiro AC, Tourneur C, Leplé JC, Combes V, Jouanin L (1992) Expression of the mutant Arabidopsis thaliana acetolactate synthase confers chlorsulfuron resistance to poplar. Transgen Res 1, 133-141

Naina NS, Gupta PK, Mascarenhas AF (1989) Genetic transformation and regeneration of transgenic neem (Azadirachta indica) plants using Agrobacterium tumefaciens. Curr Sci 58, 184-187

Nilsson O, Torsen A, Sitbon F, Little CHA, Chalupa V, Sandberg G, Olsson O (1992) Spatial pattern of cauliflower mosaic $35 \mathrm{~S}$ promoterluciferase expression in transgenic hybrid aspen trees monitored by enzymatic assay and non-destructive imaging. Transgen Res 1, 209-220

Phelep M, Petit A, Martin L, Duhoux E, Trempé $J$ (1991) Transformation and regeneration of a nitrogen-fixing tree, Allocasuarina verticillata Lam. Bio/Technology 9, 461-466

Potrykus I (1991) Gene transfer to plants: Assessment of published approaches and results. Annu Rev Physiol Plant Mol Biol 42, 205-225 
Raffa KF (1989) Genetic engineering of trees to enhance resistance to insects. Bioscience 39, 524-534

Reich TJ, lyer VN, Scobie B, Miki BL (1986) A detailed procedure for the intranuclear microinjection of plant protoplasts. Science 240 , 204-207

Roberson D, Weissinger AK, Ackley R, Glover S, Sederoff RR (1992) Genetic transformation of Norway spruce (Picea abies (L) Karst) using somatic embryo explants by microprojectile bombardment. Plant Mol Biol 19, 925935

Sautter C, Waldner $H$, Neuhaus-Url G, Galli A, Neuhaus G, Potrykus I (1991) Microtargeting: high efficiency gene transfer using a novel approach for the acceleration of micro-projectiles. Bio/Technology 9, 10801085

Szybalsky W (1989) Protection of plants against viral deseases by cloned viral genes and anti-genes. Gene 107, 177-179

Tepfer D (1984) Transformation of several species of higher plants by Agrobacterium mizogenes: sexual transmission of the transformed genotype and phenotype. Cell 37, 959-967

Thompson CJ, Movva NR, Tizard R, Crameri R, Davis JE, Lauwereys M, Botterman J (1987) Characterization of the herbicide-resistance gene bar from Streptomyces hygroscopicus. EMBO J 6, 2519-2523
Vancanneyt G, Schmidt $R$, O'connor-Sanchez A, Willmitzer L, Rocha-Sosa M (1990) Construction of an intron-containing marker gene: splicing of the intron in transgenic plants and its use in monitoring early events in Agrobacterium-mediated plant transformation. Mol Gen Genet 220, 245-250

Van der Krol AR, Mur LA, de Lange P, Mol JNM, Stuije AR (1990) Inhibition of flower pigmentation by antisense CHS genes; promoter and minimal requirements for the antisense effect. Plant Mol Biol 14, 457-466

Waldron C, Murphy EB, Roberts JL, Gustalson GD, Armour SL, Malcom SK (1985) Resistance to hydromycin G: new marker for plant transformation studies. Plant Mol Biol 5, 103-108

Wilde D, Meagher RB, Merkle SA (1992) Expression of foreign genes in transgenic yellow-poplar plants. Plant Physiol 98, 114-120

Winans S (1992) Two-way chemical signaling in Agrobacterium-plant interactions. Microb Rev 56, 12-31

Zambryski P, Joos H, Genetello C, Leemans J, Van Montagu M, Schell J (1983) Ti plasmid vector for the introduction of DNA into plant cells without alteration of their normal regeneration capacity. EMBO J 2, 2143-2150

Zambryski P (1992) Chronicles from the Agrobacterium-plant cell DNA transfer story. Annu Rev Plant Physiol Plant Mol Biol 43, 465-490 